\title{
MIR15A Pre-miRNA
}

National Cancer Institute

\section{Source}

National Cancer Institute. MIR15A Pre-miRNA. NCI Thesaurus. Code C82702.

MIR15A pre-miRNA is an oligoribonucleotide that is encoded by the human MIR15A gene and is involved in the regulation of gene expression. 